\title{
Greece-Turkey Disaster Diplomacy from Disaster Risk Reduction
}

\begin{abstract}
Disaster diplomacy examines how and why disaster-related activities do or do not reduce conflict and increase cooperation. The 1999 earthquakes in Greece and Turkey became an icon for this field of research, with numerous publications exploring how disasters might influence conflict. Fewer studies examine how disaster risk reduction might influence conflict. This paper presents a case study to explore disaster diplomacy for pre-disaster activities alongside post-disaster activities by discussing disaster risk reduction in Greece and Turkey in the context of Greek-Turkish governmental cooperation. The 1999 earthquakes are placed in context followed by an examination of disaster risk reduction in Greece and Turkey at multilateral, bilateral, and local levels. As with most disaster diplomacy case studies, disaster risk reduction for Greece and Turkey has not had a significant influence on the two countries' rapprochement.
\end{abstract}

\section{Keywords}

Balkans; disaster diplomacy; disaster risk reduction; Greece; Turkey

\section{Introduction}

This paper examines disaster risk reduction in Greece and Turkey in the context of GreekTurkish governmental cooperation, contributing to the field of disaster diplomacy. Disaster diplomacy examines how and why disaster-related activities do or do not reduce conflict and increase cooperation. Disaster-related activities refer to pre-disaster and post-disaster activities. Examples of pre-disaster activities are enacting and enforcing building codes, setting up warning systems, identifying vulnerable groups in each location, enacting measures to deal with social exclusion which creates and supports vulnerability, and putting in land use regimes that discourage development in hazardous zones. Examples of post-disaster activities are bringing in humanitarian relief, searching for survivors in collapsed buildings, clearing rubble, and starting reconstruction.

Notwithstanding earlier work on the disaster-politics nexus [22] [56] [61], studies developing and applying a disaster diplomacy framework in contemporary literature examined any spill-over effect of disaster-related cooperation to broader diplomatic cooperation. The principal case studies included Greek-Turkish relations following the 1999 earthquakes [40] [41], Cuba-USA cooperation on vulnerability to weather and climate hazards [23], and drought responses and regional cooperation in Southern Africa [27]. Examples of subsequent scholarly work include a focus on India and Pakistan [1] [39]; Iran and the USA after the 2003 Bam earthquake [36] [75]; the 2004 Indian Ocean tsunamis affecting conflicts in Sri Lanka and Aceh, Indonesia [15] [19] [45] [48]; and 
the Philippines [44]. The evidence provided by these authors confirmed the initial findings that 'disasters can catalyse but do not create cooperation among states in conflict' [20]. Apposite critiques of this work explain that it does not fully draw on previous literature while lacking succinct and consistent definitions, demonstrating a wide research agenda to still be tackled especially to improve the theorisation around disaster diplomacy [68] [78].

This paper adds a new dimension to the iconic disaster diplomacy case study of GreeceTurkey while contributing to the extension of disaster diplomacy theory to pre-disaster activities. In doing so, this paper confirms the standard disaster diplomacy hypothesis that disaster-related activities might sometimes catalyse existing diplomacy over the short-term, but neither display long-lasting effects nor create entirely new diplomacy. Previously, for the Greece-Turkey case study, this hypothesis was confirmed, especially for the 1999 earthquakes which helped to found contemporary disaster diplomacy research. The evidence provided here supports the confirmation of this hypothesis also applying to disaster risk reduction endeavours.

In order to fulfil this paper's mandate, the next section offers an overview of disaster risks and existing disputes between Greece and Turkey. Then, in section 3, this paper summarises disaster diplomacy research by examining the rapprochement efforts following the 1999 devastating earthquakes in Greece and Turkey. Next, multi-scalar approaches to disaster risk reduction are explored in the context of disaster diplomacy followed by an explanation of how little disaster diplomacy emerges for disaster risk reduction. Consequently, the standard disaster diplomacy conclusions are confirmed that disaster-related activities, in this case including disaster risk reduction rather than only disaster response, do not have a long-term impact on diplomacy.

\section{Disasters and Disputes in Greek-Turkish Relations}

The catastrophic earthquakes that hit Izmit (Turkey) and Athens (Greece) in 1999 were a tragic reminder that the two "rival states" Greece and Turkey are located in an area experiencing many types of hazards. First, the area between Greece and Turkey is highly seismically active. Over the last century, earthquakes have killed approximately 84,000 people, injured 200,000, and damaged more than 500,000 buildings in Turkey alone [63] while killing more than 1100 people in Greece [51]. Other common hazards include storms, floods, wildfires, tsunamis, and volcanic eruptions. Meanwhile, industrialisation, trade, and economic development have augmented many technological hazards such as marine pollution, waste dumping, and chemical contamination. In 2009, 48,876 ships including 9,198 crude oil and chemical tankers and liquid petroleum gas carriers passed through the Bosphorus Straits [4]. Bearing in mind the number of vessels and the fact that the straits are $31 \mathrm{~km}$ long with a minimum width of $0.7 \mathrm{~km}$ and a maximum width of $3.6 \mathrm{~km}$, oil spills are labelled as almost unavoidable [16] which, if large, would require a regional response 
including resources from and cooperation with Greece. The reason is that, although the Bosphorus Straits are part of Turkey, they connect the Black Sea and the Dardanelles Straits to the Aegean Sea that lies between the coast of Greece and Turkey (see Figure 1). Moreover, Greece, as the largest ship-owning country in the world [71] has a vital interest in ensuring that trade by sea is not disrupted by any oil spills [71].

$<$ Figure 1 here>

Despite this combination of disaster risks, cooperation between Greece and Turkey is not inevitable. The two neighbours have historically acted as rivals. From 1821 when the Greek nation revolted against the Ottoman empire until 1922 when the Turks ousted the Greeks from Asia Minor, the two were effectively in an active state of war. Following a brief interval of close cooperation starting with the Treaty of Friendship, Arbitration and Reconciliation concluded by Eleftherios Venizelos and Ismet Inonu in 1930 and epitomised with the joint entry into NATO in 1952, the growing crisis on the island of Cyprus in the late 1950s and early 1960s rekindled old rivalries. The two countries came close to being engaged in a war over Cyprus in 1974 and over sovereignty in the Aegean in 1976, 1987, and 1996. In the first case, Cyprus was the source of a bi-communal conflict between Greek Cypriots and Turkish Cypriots throughout the 1960s, but the crisis escalated when Turkey responded to a military coup on the island (supported by the military junta in Athens) by sending Turkish troops in defence of the Turkish-Cypriot minority. The result of this military intervention was the de facto division of the island.

Greek-Turkish relations further worsened with the emergence of new disputes over the delimitation of the continental shelf of the Greek islands, the extent of Greek territorial waters, national airspace and the FIR (Flight Information Region), and the militarisation of Greek islands in the eastern Aegean Sea. In 1976 and again in 1987, the crisis between the two countries escalated when Turkish ships conducted research on what Greeks consider part of their Aegean continental shelf, so Greece interpreted this research as questioning Greek sovereignty in the Aegean and the Greek delimitation of the continental shelf.

In 1996, Greece and Turkey came to the brink of war over the sovereignty of two uninhabited islets called Imia/Kardak. The Imia/Kardak question emerged when the Turkish cargo boat Figen Akat ran aground near a small islet 2.5 miles off the coast of Kalolimnos. While the captain initially refused assistance by the Greek authorities claiming that the incident occurred in Turkish territorial waters, the boat was finally assisted by a Greek salvage company. Following actions by the Greek mayor of Kalymnos who raised a Greek flag on the rock and Turkish journalists who replaced the Greek with a Turkish flag, the Greek government sent military troops on the Imia/Kardak rocks claiming sovereignty. Turkey strongly protested and demanded the withdrawal of the Greek troops and flag. The situation quickly escalated and the two fleets came close to a military confrontation 
which was avoided only after the intervention of the USA, with the EU backing Greece. The significance of the crisis was that Turkey for the first time started to question the legal status of some scattered islands in the Aegean. Coining the term 'grey areas', Turkey initiated a policy of bringing sovereignty issues onto the agenda of Turkish-Greek relations [12] [55].

\section{A Disaster Diplomacy Perspective}

Given these disputes and the historical enmity [57], the heartfelt aid offered by Greece following the 17 August 1999 earthquake in Izmit (Kocaeli, Turkey) and the equally earnest Turkish aid to Greece following the 7 September 1999 earthquake in Athens (Greece) could be seen as almost paradoxical. The two devastating earthquakes that killed more than 17,000 people in Turkey and 143 people in Greece spurred an unprecedented spirit of cooperation. Both governments reciprocally provided humanitarian aid through the Red Cross and Red Crescent Society while deploying medical and special rescue teams (Greek EMAK and Turkish AKUT teams) to assist their counterparts.

These responses cannot be assumed to be disaster diplomacy per se. Explorations of community cohesion and connections post-disaster go far back into the literature [61]. Insights are offered by the notion of post-disaster 'therapeutic community' [2], although others had previously proposed and explored such concepts and critiques are also evident [10]. Therapeutic communities refer to informal or grassroots offers of social (e.g. empathy) and physical (e.g. shelter and food) support after a disaster, which happens commonly even if the majority might express indifference or even hostility. Factors are examined to indicate why some are willing to render assistance and the type and time scale of help [2]. How might a therapeutic community link to disaster diplomacy or other political influences?

For Greece and Turkey, the people's reaction signalled the changing political situation. In the aftermath of the earthquakes, Greek and Turkish nationals were lining up to offer cash, clothing, other supplies, and blood donations. Some even volunteered to donate their kidneys to survivors [43]. The support was reflected in newspaper headlines and media reports. Following the rescue of a Turkish boy by EMAK, the Turkish daily Milliyet on 19 August 1999 suggested that the image of Greeks and Turks had now changed in each other's country. Confirming this observation, the largest Greek newspaper Ta Nea wrote 'We all are Turks' on 20 August 1999. Similarly, when the Turkish team AKUT rescued a Greek boy in Athens, Turkish newspapers published headlines in Greek and Turkish saying 'Get well soon neighbour' [28].

The reciprocal emergency assistance provided by the two countries and the emergence of a favourable environment for cooperation gave impetus to discussions of 'disaster diplomacy' [37] [38]. Disaster diplomacy framings have been analysed in detail for Greece and Turkey. The people- 
to-people spirit of cooperation following the 1999 earthquakes effectively legitimised a political rapprochement process that had begun earlier in 1999 by the Greek and Turkish Foreign Ministers George Papandreou and Ismail Cem respectively [40] [41], although others [52] trace it back to 1996 in the aftermath of the Imia/Kardak crisis. In Keridis' words 'the earthquakes happened on fertile ground ready for change [...] provided a new impetus and brought societies and the media into the process of rapprochement' [39]. Following an exchange of letters between the two ministers in May/June 1999, a working group was set up to address less contentious issues such as tourism, environment, illegal immigration, organized crime, and terrorism. After the earthquakes, these bilateral talks gained momentum leading to the two countries signing dozens of bilateral agreements, protocols, and Memoranda of Understanding (MoU) between 1999 and 2009. They further adopted, through bilateral meetings or within NATO, twenty-four Confidence-Building Measures (CBMs), increasing trust between them [67]. Prior to 1999, the two countries had signed a total of 19 bilateral agreements, ten of which were signed in the 1920s and 1930s to settle their remaining disputes shortly after World War I and Turkey's War of Independence [67].

In terms of bilateral trade, the figures are impressive. Between 1998 and 2008, the trade volume increased approximately six-fold reaching €3.6 billion [29] [46]. By 2009, 480 Greek companies were operating in Turkey while Greek investments exceeded $€ 6.5$ billion. This situation made Greece the third largest investor in Turkey after the Netherlands and the USA, although that was due mainly to the takeover of the Turkish Bank Finansbank by the National Bank of Greece in a deal worth approximately US\$4.5 billion. Other joint projects included the Karacabey-Komotini, Nabucco, and Turkey-Greece-Italy Interlocutor pipelines which to bring natural gas from Azerbaijan and Turkmenistan to Europe [31] [32].

Post-earthquake governmental changes in Greece (2004) and Turkey (2003) did not interrupt the rapprochement process. The New Democracy Party in Greece (Nea Dimokratia) and the AK Parti (Justice and Development Party) adopted the rapprochement rhetoric and public discourse of their predecessors. Between 2003 and 2007, Recep Tayyip Erdoğan visited Greece four times either in his capacity as leader of AKP or as Turkish Prime Minister. In 2007, his counterpart, Costas Karamanlis, became the first Greek Prime Minister since 1959 to visit Ankara. At the level of Foreign Ministers, the regular exchange of visits between Ministers Dora Bakoyanni and Ali Babacan and the signing of several CBMs, illustrated the continuation of the momentum created by Papandreou and Cem. In terms of policy, while Greece shifted its position championing Turkish EU membership, Turkey embraced the UN-sponsored plan to reunify Cyprus (which nonetheless failed in the end).

Throughout, the two countries have consistently avoided confrontation despite many instances of crisis, dangers of escalation, and regional geopolitics. In April 2004, a unification 
referendum failed in Cyprus, putting the Greeks and Turks at loggerheads. The following year, during the Greek Foreign Minister's Petros Molyviatis official visit to Ankara, a new crisis broke out over Imia/Kardak but it did not lead to any escalation. Similarly, when a Greek pilot was killed while intercepting a Turkish military aircraft over the island of Karpathos in May 2006, the Greek and Turkish foreign Ministers expressed their regret and agreed not to allow the incident affect the rapprochement process [64]. The global financial crisis nearly leading to Greece's withdrawal from the Eurozone, political instability and multiple government changes in Athens, differences between Ankara and Athens over Balkan geopolitics particularly for Kosovo and the Former Yugoslav Republic of Macedonia (FYROM), disputes between Turkey and Brussels regarding its accession to the EU, and major protests and terrorist attacks in Turkey alongside Syria's war did not derail Greek-Turkish relations. Despite major differences on some issues, the two countries carefully managed these episodes through ongoing and constructive dialogue without breaking down their longer-term ties.

The 2009 parliamentary elections in Greece raised new hopes as the leader of the Socialist party (PASOK) George Papandreoiu, who had introduced the rapprochement process ten years earlier was elected Prime Minister. Acting in his capacity as foreign minister, Papandreou chose his first trip abroad to be a meeting with fellow ministers from Southeastern Europe in Istanbul [53]. The apogee of the 10-year rapprochement process was Recep Tayyip Erdoğan's sixth visit to Athens on 14 and 15 May 2010, which marked the launching of the Turkey-Greece High Level Cooperation Council co-chaired by the two Prime Ministers [35]. A total of 320 people (including 10 ministers, several government officials and more than 100 businessmen) accompanied the Turkish Prime Minister and celebrated the signing of 21 bilateral Agreements and Memoranda of Understanding.

Although the territorial disputes were discussed at the highest level, these Agreements focused exclusively on low-politics including education, economic and trade relations, energy, the environment, culture, tourism, transport, and communication and European affairs. While no significant progress was made to resolve the salient larger questions, the two Prime Ministers pledged to intensify the talks and open some windows of hope for settling the long-standing disputes [69] [70].

With respect to all these initiatives, what role did disaster-related activities play? The 1999 earthquakes and their role on Greek-Turkish diplomacy have been examined in-depth [13] [20] [40] [41] [49] [52] [77] with the conclusion that the earthquakes catalysed the rapprochement, but did not create it. What role, if any, did disaster risk reduction strategies play alongside disaster response?

\section{Multi-Scalar Disaster-Related Activities}


This section reviews some disaster risk reduction strategies implemented jointly by Greece and Turkey at multiple governance scales. The changes happened in the context of national changes as well because the 1999 earthquakes had seriously challenged existing national disaster management structures and policies in Greece and Turkey. Consequently, to provide some background, section 4.1 briefly reviews some of the national changes which happened separately in Greece and Turkey. Then, section 4.2 looks at bilateral disaster-related cooperation between the two national governments. Section 4.3 scales down, detailing cross-border local cooperation for disaster-related activities, mainly linked to river flooding and including Bulgaria. Given wider Balkan and European issues emerging from the local collaboration, section 4.4 jumps up to the regional level, examining Greece and Turkey's involvement in regional initiatives for disaster risk reduction and disaster response.

The text on this section focuses on post-1999 initiatives. Before, little substantive was happening for Greece-Turkey collaboration with respect to disaster-related activities, even though section 3 demonstrated that plenty was happening diplomatically between those two countries. The few disaster risk reduction initiatives which were in progress are mentioned in the relevant section to provide the needed baseline.

\subsection{National-level changes}

The 1999 earthquakes demonstrated inadequacies in dealing with disasters at the national level separately for Greece and for Turkey. Consequently, the Greek and Turkish governments each reformed their national civil protection structures through legislative changes.

In Greece, the Law 3013 (ФEK 102/1-5-2002) revised the Civil Protection system and the Emergency Plan Xenocratis, assigning overall responsibility to the General Secretariat for Civil Protection and specific tasks and responsibilities to regional and local authorities. In Turkey, the need for coordination and preparedness led to the establishment of the General Directorate of Turkish Emergency Management within the Prime Minister's Office. In 2009, the low level of communication and coordination and the overlapping responsibilities led the Turkish government to merge the activities of the Emergency Management General Directorate under the Prime Minister, the General Directorate of Disaster Affairs under the Ministry of Public Works and Settlement, and the General Directorate of Civil Defence under the Ministry of Interior. The new Department, based within the Prime Minister's Office is called Disaster and Emergency Management Presidency (DEMP). It oversees six departments on Planning and Mitigation, Earthquake, Recovery, Civil Defence, Response and Administrative Affairs with the new law decentralizing so that more power and responsibility end up with local authorities [60]. 
A large programme in disaster risk reduction was also introduced in partnership with the World Bank covering projects in preparedness, disaster recovery, hazard mitigation, infrastructure reconstruction, and institutional development [76]. In 2000, assisted by the World Bank, Turkey started the Turkish Catastrophe Insurance Pool (TCIP) which now covers millions of residences against earthquake damage [11] [76].

\subsection{Bilateral Disaster-related Cooperation}

In the wake of the 1999 earthquakes, the Greek and Turkish Foreign Ministers, George Papandreou and Ismail Cem, announced the creation of a joint disaster response team. This initiative culminated with the submission of a joint proposal to the UN for the creation of a Joint Hellenic-Turkish Standby Disaster Response Unit (JHET-SDRU). The draft resolution for the team was unanimously adopted by the 54th UN General Assembly (A/RES/54/30 Emergency Response to Disasters) on 22 November 1999 [21]. This was supplemented by a bilateral protocol signed on 8 November 2001 in Athens. The protocol would last a decade, but would be automatically renewed every five years unless terminated by either party. The focal points for bilateral communication and operational implementation of the protocol are the General Secretariat for Civil Protection (GSCP) of the Ministry of Interior, Public Administration and Decentralization in Greece and the General Directorate of Emergency Management of the Prime Ministry (GDEM) in Turkey.

The JHET-SDRU protocol states that the team consists of two national teams, with 40 members each. The national teams are to be selected by each country from governmental and nongovernmental organizations (e.g., AKUT, EMAK) and will remain at their permanent home base locations. Its mission will be to respond to disasters (listed as earthquakes, floods, and landslides) in the broad vicinity of the two countries and the wider Mediterranean area, undertaking tasks such as joint training, search and rescue operations and emergency medical care. They will join together for training - thereby incorporating disaster risk reduction-and emergency response. A Coordinating Committee oversees the organizational, financial, operational, and scientific issues of the unit, reporting to both governments. The Committee consists of 5 members from each country and is chaired on a rotating basis by representatives from the GSCP (Greece) and GDEM (Turkey). Other Greek participants include the General Directorate for International Development Cooperation (YDAS) of the Greek Ministry of Foreign Affairs, the Greek Fire Service, the National Centre for Emergency Care (EKAB) and the Earthquake Planning and Protection Organisation (OASP). Turkish officials from the Ministry of Health and the Prefecture of Ankara have attended Committee Meetings [14].

Following an MoU with the UN Office for the Coordination of Humanitarian Affairs (UNOCHA), the JHET-SDRU mandate was expanded to international humanitarian emergency 
response upon the request of the United Nations. Under such circumstances, each state funds its own national component, but the team members are entitled to UN experts' privileges and immunities as specified by the UN General Assembly. The MoU also outlines several other areas of collaboration for disaster risk reduction and disaster response, including holding forums on disaster preparedness, exchanging information in emergencies, training the unit, and conducting command post and field exercises.

The two countries have since been undertaking joint disaster preparedness training and drills to prepare JHET-SDRU such as the search-and-rescue map exercise on 11 December 2006 in Ankara with the participation of Greek-Turkish civil defence teams. Furthermore, Athens hosted a training seminar on 20-21 March 2007 where representatives from both countries received training from UNOCHA to be familiarized with the UN's disaster response mechanisms [21]. On 14 December 2010, within the framework of the JHET-SDRU Protocol the Greek General Secretariat for Civil Protection organised the first ever real-time joint exercise at the rubble of a factory in Athens. 15 EMAK rescuers with 5 search-and-rescue vehicles from Greece were joined by 10 Turkish rescuers from Izmir with 3 special vehicles and rescue equipment [24]. Joint exercises were also conducted between military disaster response units in Turkey in November and December 2006.

In addition to JHET-SDRU, Greek and Turkish Armed Forces have been collaborating to improve their collective disaster response capacities. For this purpose, the two armies conducted their first joint disaster response exercise in Turkey on 8 November 2006, followed by another one in Greece on 14 May 2008, with participation from their military disaster response units: the Greek KOMAK and the Turkish DAK. In both exercises, the scenario involved a large earthquake with joint rescue operations by Greek-Turkish teams [33]. These exercises were incorporated into the framework of the CBMs agreed by Greek Foreign Minister Dora Bakoyannis and her Turkish counterpart Abdullah Gül in 2006 and in 2007 with the Turkish Foreign Minister Ali Babacan. Ms. Bakoyannis and Mr. Babacan agreed inter alia to create 'a combined joint Disaster Relief/Humanitarian Aid Task Force capable of covering a wide range of missions and areas' [25]. Establishing the joint disaster response unit was also discussed during the visit of the Turkish Chief of General Staff to Greece [6].

Tsunami diplomacy provides further bilateral and multilateral cooperation for disaster risk reduction. The Eastern Mediterranean has significant tsunami threats, due to both earthquakes and volcanic eruptions. According to historic records, the Aegean islands and the West coast of Turkey have been affected by at least 20 major tsunamis in human history. Those include the Minoan tsunami of the seventeenth century BC produced by the eruption of the Thera (Santorini) volcano; 
the 1956 tsunami caused by an earthquake that severely damaged the island of Amorgos; and the 2002 tsunami that hit the city of Rhodes [58].

Following the 2004 tsunamis around the Indian Ocean, a formal process to set up a tsunami warning system for the Indian Ocean was started and the members of the UNESCO Intergovernmental Oceanographic Commission (IOC) decided to establish similar systems in other bodies of water. Thus, in 2005 the IOC member states created an Intergovernmental Coordination Group for the Tsunami Early Warning and Mitigation System in the Northeastern Atlantic, the Mediterranean, and connected seas (ICG/NEAMTWS). Greek and Turkish experts and foreign ministry officials have been actively participating in the regular sessions of the coordination group and have greatly contributed in establishing a system of national and regional tsunami warning centres (NTWC, RTWC).

By 2008, the Task team for the RTWC tabled a set of proposals regarding collecting and sharing seismic and sea level data, assessing hazards, raising public awareness, and disseminating alerts and warning messages to national authorities [30]. Given that by 2009, Italy, Turkey, Greece, and Portugal were on a 24/7 watch mode, they were invited to act as a RTWC and offer their services to other countries. In response, the representatives of the Turkish Kandilli Observatory and Earthquake Research Institute (KOERI) claimed that 'the institution is ready to provide regional coverage for the Eastern Mediterranean in collaboration with Greece' [30, Annex IV, p. 2]. The simultaneous proposals by Greece and Turkey to create regional warning centres covering the Aegean and the Eastern Mediterranean are not coincidental.

For a warning system in the Aegean and the Eastern Mediterranean to be effective, the two neighbouring countries need to overcome differences regarding territorial waters and the continental shelf. As a signatory to the 1982 UN Convention on the Law of the Sea (UNCLOS), Greece reserves the right to extend its territorial waters to 12 nautical miles and therefore to perform economic activity plus search-and-rescue operations in that area. Turkey contests this by claiming that such a development would turn the Aegean into a Greek sea and so territorial waters should be confined to six miles. Finally as shown in the Imia/Kardak incident, Turkey challenges Greek sovereignty over several islets in the Aegean. Given these disagreements, the fact that neither centre has shared online data information gathered from its automatic tide gauges is indicative of the remaining problems [34].

\subsection{Local-level Disaster-Related Cooperation}

The Meriç (Evros) River which flows from Bulgaria and draws the border between Greece and Turkey gradually became a test case for what has been coined as "hydrodiplomacy" [54]. Flooding incidents have been a constant concern of the local authorities of these three countries and 
they have recently increased in frequency and volume with catastrophic consequences, especially in downstream areas in Greece and Turkey. National responses have remained insufficient, fragmented, uncoordinated, and underfunded.

These shortcomings were acknowledged by the Greek Prefect of Xanthi, George Pavlidis, who launched an initiative in 2002 to create a "Cross-border Cooperation Network of Border Prefectures". The Greek Prefect described the initiative as a 'bottom-up process as opposed to the pre-existing EU schemes of cross-border cooperation' [59]. The network includes six Prefects from Greece, four from Bulgaria, and one from Turkey (Edirne). The main objective was to exchange information and forge cooperation on dealing with disasters, pandemics, environmental pollution, and illegal immigration as well as cooperation in tourism and culture. Since 2003, the Prefects have held regular meetings to foster cooperation including for disaster risk reduction and disaster response.

The continuing lack of infrastructure, lack of funds (despite the INTERREG programme which provides funding for inter-regional cooperation across Europe include EU and non-EU countries), and low levels of communication and coordination with the Bulgarian authorities limited the ability of Greece and Turkey to respond to the 2005 and 2006 floods, which were the worst in over 50 years. The result was the evacuation of villages in Greece and Turkey, the destruction of thousands of acres of crops in both countries, and the displacement of thousands of people in Edirne [3] [42]. Drawing on the experience of the 2005 and 2006 disasters, the Prefects of Evros in Greece and Edirne in Turkey met on a daily basis in November 2007 in order to reinforce the river banks and save the Greek village of Nea Vissa. This was the first time that Greek and Turkish teams worked together [50]. The 2005 and 2006 floods generated further public pressure for a long overdue agreement between Turkey and Bulgaria on the establishment of early warning stations at the Bulgarian part of the river. It was also agreed to construct a dam at the Bulgarian-Turkish border, near the village of Suakacagi. This project had remained frozen for decades due to territorial disputes between the two countries.

Nonetheless, in the following years, little progress was made in terms of bilateral or trilateral agreements on the protection and management of the river. The existing bilateral and multilateral agreements signed between the neighbouring countries soon became obsolete and proposals for joint projects fell victim of the lack of communication and of historical rivalry amongst the three states of Turkey, Greece, and Bulgaria. With regards to Turkey, 'in transboundary cases as river Evros/Meric the particular national interest is prevailing and is closely linked to the "defence/security dimension" which is considered an issue of higher priority (military discourse)' [66, p. 136]. 
Recently, the EU-funded INTERREG IIIC/PHARE Cross-border Cooperation Programme between Greece and Turkey was never implemented due to continuing territorial disputes. The INTERREG III/A Turkey-Greece Programme approved by the Commission in 2003 aimed at developing cross-border cooperation and improving the life of the inhabitants of adjacent neighbouring areas as well as improving accessibility, communication, and environmental management and hence including disaster risk reduction measures. By 2006, the programme was suspended and the European funds were automatically de-committed as it became impossible to implement the programme due to lack of political agreement [62]. According to the Greek Foreign minister, Ms. Dora Bakoyanni, the suspension of the programme was due to Turkish reservations regarding the terminology used in the programme, such as asking to clarify or redefine the term 'cross-border'. Greece rejected the need to redefine the term which is used in similar projects with other neighbouring countries [17] [26].

The High Level Cooperation Council inaugurated in Athens in May 2010 raised some optimism with the signing of a Joint Declaration by the Greek Minister of Environment, Energy and Climate Change and the Turkish Minister of Environment and Forestry. The ministers agreed 'to establish and operate a system of permanent cooperation for the sustainable development of the river basin to improve living standards in the riverine areas, to prudently use environmental resources, to conserve natural and cultural heritage and to strengthen the friendship ties between Greek and Turkish people' [9, p. 9]. In addition to water management measures aiming to reduce pollution and ensure a stable and controlled water supply to the local populations, which would assist with flood risk reduction, the Declaration also invited all countries sharing the river basin 'to take necessary measures to manage the flood problem' and to 'apply best available techniques including the establishment of flood early warning system' [9, p. 10].

\subsection{Regional Disaster-related Collaboration}

Prior to the earthquakes, disaster-related collaboration between Greece and Turkey was restricted mainly to multilateral frameworks, without much bilateral contact. After the earthquakes, the need for regional cooperation and coordination led to the launching in November 2000 of the Disaster Preparedness and Prevention Initiative (DPPI) for South East Europe involving 12 member states: Albania, Bosnia-Herzegovina, Bulgaria, Croatia, Former Yugoslav Republic of Macedonia, Greece, Hungary, Moldova, Romania, Serbia and Montenegro, Slovenia, and Turkey. Initially funded by the Stability Pact for South Eastern Europe, the DPPI fostered cooperation through sharing information, drawing lessons, identifying good practices, enhancing early warning systems, and increasing planning and preparedness. It also provided guidelines and common practices while becoming a pool of information regarding the development of disaster emergency legislation, 
environmental regulations, and codes. On 27 February 2008, the Stability Pact for South Eastern Europe was replaced by the Regional Cooperation Council in order to be more "regionally owned" as opposed to being directed by outside actors such as the EU.

The Organisation of the Black Sea Economic Council (BSEC) is another regional organisation fostering cooperation for disasters. Initially, this Turkish initiative aimed at establishing economic and political cooperation amongst the littoral countries (Bulgaria, Georgia, Romania, Turkey, Ukraine, and Russia) but adjacent states with economic interests in the Black Sea (Albania, Armenia, Azerbaijan, Greece, and Moldova) were invited to join as founding members. In 1998, its activities expanded to include collaboration in emergency assistance and emergency response to disasters. In 2005 the member states further enhanced disaster-related cooperation by signing an Additional Protocol establishing a network of liaison officers on Emergency Assistance.

In terms of non-regional actors, the United Nations, the World Bank, and the European Union encouraged and supported financially, institutionally, and technically the development of regional disaster risk reduction and disaster response structures. The United Nations International Strategy for Disaster Risk Reduction (UNISDR) has been a crucial catalyst post-earthquakes. UNISDR's key document from 2005-2015 was the Hyogo Framework for Action (HFA) [72] which is a blueprint for disaster risk reduction from 2005-2015. It is now superseded by the Sendai Framework for Disaster Risk Reduction (SFDRR) 2015-2030 (SFDRR) [74]. Through HFA and SFDRR, UNISDR has consistently promoted a European Regional Platform where national representatives (referred to as National Platforms and HFA representatives) exchange information, promote concerted regional proposals, train at regional and sub-regional level, and identify lessons. The work identifies areas where transnational cooperation amongst the South Eastern European countries would be most valuable, namely sharing vulnerability information (through maps and models), establishing transboundary monitoring and early warning systems, and enhancing communication amongst scientific bodies and civil protection organisations. These provide examples of Greece-Turkey disaster risk reduction cooperation being enacted at the multilateral level.

Turkey working towards joining the European Union could facilitate the development of effective and efficient disaster risk reduction and disaster response structures and policies operating at local, national, or regional levels. As Turkey gradually becomes integrated into EU institutions, it gains access to EU financial resources and technical expertise provided that EU norms, rules, and procedures are followed. For example, the EU has given particular attention to establishing crossborder cooperation by introducing the INTERREG programmes as instruments to enhance cooperation and improve the living standards across the borders. Cross-border water cooperation was included in the European Commission's 2006 report on Turkey's progress towards accession where the Commission called upon Turkey to step up with neighbouring countries for implementing 
the Water Framework Directive and transboundary water cooperation which would enhance flood risk reduction [5].

In 2007, the EU replaced INTERREG with the European Territorial Cooperation Objective 2007-2013. Simultaneously, it introduced an Instrument for Pre-Accession Assistance (IPA) that supported, inter alia, 'cross-border cooperation at terrestrial and maritime borders between EU countries, candidate and potential candidate countries' [7, p. 50]. In 2008, the European Commission launched a Disaster Risk Reduction Initiative, financed by $€ 2$ million yearly through the Instrument for Pre-accession Assistance (IPA) in order to build capacity, to improve data sharing, and to develop a regional disaster risk reduction strategy [73]. Despite the new instruments and resources available to Greece and Turkey under the IPA cross-border cooperation programme “Greece-Turkey 2007-2013”, even by 2011, no programme had been submitted for approval [18].

In 2013-2015, the Council of Europe, of which both Greece and Turkey are members, led an initiative on disability and disaster. One output was a toolkit [65] which included examples from both countries of working with people with disabilities for disaster risk reduction and disaster response. The Council of Europe is also responsible for the EUR-OPA Major Hazards Agreement which provided a platform for political and scientific cooperation in disaster management and prevention. It was signed in 1987 by Greece, Turkey, and ten other countries and its work continues today.

The Euro-Mediterranean Partnership where both Greece and Turkey participate also addresses a disaster prevention and management system through cooperation among civil protection authorities on disasters, which can have links to and influences with civil defence and military defence. The participating Ministers have repeatedly discussed the issue of a Euro-Med system of disaster prevention, starting before the earthquakes such as at the Third Euro-Mediterranean Ministerial Conference from 15-16 April 1999 in Stuttgart, Germany. This work continued afterwards: In 2005, along with the other signatories of the Euro-Mediterranean Partnership, Greece and Turkey pledged further work on emergency, security, defence, and disaster prevention topics [8].

Within the framework of the Euro-Mediterranean Partnership, and in particular the Security and Political Dialogue, the member states launched the EuroMed Programme for the Prevention, Preparedness and Response to Natural and Man-made Disasters 2008-2011 and a forum of Mediterranean Coast Guard Services for maritime safety [47]. The 2008 Joint Declaration of the Paris Summit for the Mediterranean on Bastille Day, 14 July, highlighted as priorities pollution reduction in the Mediterranean and the creation of a joint Civil Protection programme on prevention of, preparation or, and response to disasters. 


\section{Implications for Disaster Diplomacy}

The multi-scalar collaborations between Greece and Turkey on disaster-related activities show few results in terms of generating and perpetuating inter-governmental cooperation. For earthquakes and tsunamis, numerous initiatives continue bilaterally, based mainly on the momentum from, respectively, the 1999 earthquakes and 2004 Indian Ocean tsunamis. These initiatives, though, are to a large degree divorced from wider rapprochement; no longer are they affected nor do they affect wider Greece-Turkey relations. Similar results are seen for wildfires. Greece and Turkey offer each other assistance, some of which is realised, but as shown by wildfire disasters - for instance, in August 2009 when Turkey offered Greece support to deal with a firestorm-wildfire diplomacy happens bilaterally and locally, but with no apparent influence on other forms of bilateral relations or on regional multilateral endeavours. Meanwhile, at the local level, flood diplomacy and hydrodiplomacy are being enacted.

At the national level, mixed results are visible, despite ample opportunity for more to be done. Further to reforming the national structures, the most important effect of the 1999 earthquakes was to underline the vulnerability of both countries to disasters and the limited capacity of national disaster management structures to respond to such hazards on their own, mainly due to the high vulnerability which has not been fully addressed in either country. Yet recognising and accepting the transboundary nature of hazards and disasters, a momentum of close cooperation and consultation for disaster risk reduction emerged. The two countries introduced new bilateral instruments for disaster risk reduction and disaster response to complement pre-existing national and regional structures. Little direct spillover was seen at the multilateral level, especially because regional and international disaster-related endeavours often continued irrespective of the Athens-Ankara relationship.

The opportunity remains for the national governments to take the lead and to support the local initiatives along with the opportunity to build on the past and existing disaster-related cooperation for further work including at the multilateral level. Those opportunities are not being fully grasped because wider issues are permitted to influence. For instance, in the case of floods, the politics of nationalism are a preferred interest over long-term, local or multilateral disaster risk reduction. Nonetheless, the small steps that are being taken at the national and regional levels, coupled with operational collaborative actions at the local level, provide a base for water-related disaster diplomacy that might lay the foundation for continuing progress. It seems, though, that spill-over into other areas of diplomacy are unlikely to emerge, either locally, bilaterally, or multilaterally.

In fact, in the absence of a political commitment and clear national governmental policies, the results of local initiatives will tend to be limited to local areas, although potentially inspiring other local areas to emulate them. This situation does not diminish the local level links that are forged due 
to disaster-related activities. Similarly, many disaster diplomacy case studies display failure at the national level, but some degree of success at the local level. Examples are Cuba-USA [23] and Hurricane Katrina [36]. Those local successes rarely scale up to bring national governments closer together bilaterally or multilaterally, although they sometimes succeed because the national governments do not focus on the local work and therefore do not get involved or interfere. Greece/Turkey as a case study does not provide an exception.

Nevertheless, the numerous disaster-related initiatives at difference governance levels illustrate that Greece and Turkey acknowledge that hazards, vulnerabilities, and disasters can be transboundary and hence require cross-border and international efforts regarding coordinated disaster risk reduction and disaster response. The 1999 earthquakes were key in forcing that realisation at both theoretical and operational levels, as shown by the limited interaction that Greece and Turkey had on disaster-related matters prior to the earthquakes [20]. But limited interaction is not the same as no interaction, plus the links extend back several years [52]. Consequently, a basis existed from which further work could emerge, with the 1999 earthquakes catalysing disasterrelated cooperation, including for disaster risk reduction, in the context of catalysing Greek-Turkish rapprochement overall.

Greek-Turkish relations have continued to be strengthened despite persistent territorial and political disputes, major political changes, and numerous forms of crisis in the countries and around the regions. In parallel, the various disaster-related activities have proceeded-multilaterally, bilaterally, and locally_even when separated from high-level political negotiations (e.g. earthquake rescue training) and even when faltering through being more enmeshed in national-level politics (e.g. national-level hydrodiplomacy).

Overall, disaster risk reduction diplomacy for Greece and Turkey effectively divorces the disaster-related activities from the joint rapprochement. The collaboration was certainly pushed forward by the 1999 earthquakes in the same way that disaster response diplomacy was. But a foundation for the disaster risk reduction efforts existed beforehand, both in terms of the preearthquake diplomatic efforts and the pre-1999 disaster risk reduction activities such as the EUROPA Major Hazards Agreement. Consequently, the disaster risk reduction efforts were catalysed but not created by the earthquakes. In the short-term, the leadership in the diplomacy assisted in providing a foundation for joint disaster-related efforts. In the long-term, the diplomacy and the disaster risk reduction separated.

An expansion of the standard disaster diplomacy conclusion is provided in that the earthquakes and subsequent diplomacy catalysed, but did not create, the disaster risk reduction activities. The catalysis had influence in the short-term, but not in the long-term. Why this situation recurs has explanations as alluded to above, including nationalism and lack of political will to 
actively effect disaster diplomacy. These suggestions do not describe the root reasons for disaster diplomacy's failure. Instead multiple case studies converge on the fundamental reason for disaster diplomacy's failure that political impetuses exist for decisions other than dealing with disasters and enacting diplomacy [37]. Disaster diplomacy could work only if both activities are desired and sought by most parties, but that situation does not always exist. Instead, decision-makers can be looking out for their own career interests, can use conflict to bolster their political career, can prefer enmity for nationalistic or cultural reasons, or can prefer to allocate time and resources to activities other than peace-making and dealing with disasters.

\section{Conclusions: Wither Disaster Diplomacy?}

Overall, disaster-related cooperation is occurring between Greece and Turkey, for both disaster risk reduction and disaster response, but without links to other forms of cooperation or diplomacy. This situation is typical of other disaster diplomacy case studies [37]. The disaster diplomacy hypothesis that disaster-related activities can catalyse but not create diplomacy was previously confirmed for Greece-Turkey after the 1999 earthquakes [40] [41]. The evidence here supports the idea that this hypothesis could be confirmed for disaster risk reduction endeavours as well.

The material here also supports prior analysis [37] regarding the deliberate use of disaster diplomacy as a specific strategy for effecting disaster-related activities, diplomacy, or both together. The potential disaster diplomacy instances for Greece and Turkey have been pursued with a mixture of inadvertent and deliberate goals. While many in the media and grassroots sought disaster diplomacy actively following the 1999 earthquakes, those in government were pulled along by events. Post-1999, disasters and disaster risk reduction efforts were, in effect, followed in parallel with diplomatic efforts, rather than in tandem. Irrespective of disaster diplomacy's potential being pursued deliberately or inadvertently, the same outcome was observed, confirming the standard disaster diplomacy hypothesis of disaster-related activities catalysing rather than creating diplomacy. As with the overview of "active" and "passive" disaster diplomacy previously analysed [37], the Greece-Turkey case study further affirms that the main disaster diplomacy hypothesis.

All such evidence, discussion, and conclusions presented throughout this paper support disaster diplomacy work on Greece-Turkey and other case studies showing that post-disaster diplomacy rarely has a long-term impact on diplomacy, including conflict reduction and conflict resolution [23] [27] [36] [37] [40] [41]. Instead, disasters sometimes have a catalytic effect in the short-term, accelerating an ongoing diplomatic process. For catalysis, a pre-existing basis is needed 
for the diplomacy and, irrespective, non-disaster-related factors dominate diplomacy in the longterm. Here, for Greece and Turkey, the evidence shows that this overall disaster diplomacy conclusion holds for pre-disaster diplomacy as well, namely through disaster risk reduction activities. Hence, disaster risk reduction diplomacy displays the same lack of effect which has so far been observed in wider disaster diplomacy.

\section{References}

[1] S. Akcinaroglu, J. M. DiCicco, and E. Radziszewski, 'Avalanches and Olive Branches: A Multimethod Analysis of Disasters and Peacemaking in Interstate Rivalries', Political Research Quarterly, 64(2), 2011, pp. 260-275.

[2] A. Barton, Communities in Disaster: A Sociological Analysis of Collective Stress Situations, Basic Books, New York, New York, 1969.

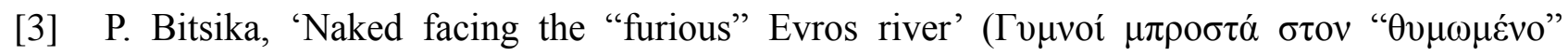

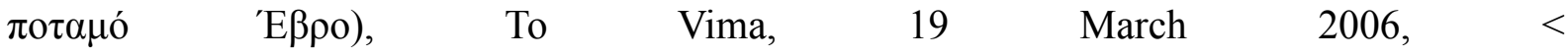
http://www.tovima.gr/default.asp?pid=2\&ct=75\&artid=172021\&dt=19/03/2006 > (accessed date 14 December 2015).

[4] Bosphorus Strait News, 2009, < http://www.bosphorusstrait.com/category/monthly-shipstatistics > (accessed on 14 December 2015).

[5] Commission of the European Communities, Turkey 2006 Progress Report, Commission Staff Working Document, COM (2006) 649 final, Brussels, Belgium, 8 November 2006.

[6] Commission of the European Communities, Turkey 2007 Progress Report, Commission Staff Working Document, COM (2007) 663, Brussels, Belgium, 6 November 2007.

[7] Commission of the European Communities, MED Operational Programme 2007-2013, (CCI 2007 CB 163 PO 045), Version adopted by the European Commission, Decision C (2011) 1706, 16/3/2011, Brussels, Belgium, 2011, < http://www.programmemed.eu/fileadmin/PROG_MED/Appels_offres/APPEL_Innovation_En ergy/EN-OP_Med_2012.pdf > (accessed 14 December 2015).

[8] Council of the European Union, 10th Anniversary Euro-Mediterranean Summit, Barcelona, 27 and 28 November 2005, Five Year Work Programme, Brussels, 28 November 2005, 15074/05 (Presse 327), < http://www.euromedseminars.org.mt/archive/ministerial/Barcelona+10-5YearProgramme-w.pdf > (accessed 14 December 2015). 
[9] Council of the European Union, Memorandum of Understanding in the field of Forestry between the Government of the Hellenic Republic and the Government of the Republic of Turkey, and of a Joint Declaration between the Minister for Environment, Energy and Climate Change of the Hellenic Republic and the Minister for Environment and Forestry of the Republic of Turkey - Information from the Greek delegation, Brussels, 4 June 2010, $10524 / 10$

http://register.consilium.europa.eu/doc/srv?l=EN\&f=ST\%2010524\%202010\%20INIT > (accessed 14 December 2015).

[10] B.H. Cuthbertson and J.M. Nigg, 'Technological Disaster and the Nontherapeutic Community: A Question of True Victimization', Environment and Behavior;, 19(4), 1987, $462-483$.

[11] DASK, Turkish Catastrophe Insurance Pool - TCIP Compulsory Earthquake Insurance (CEI), Annual Report 2011, Istanbul, Turkey, 2011, < http://www.tcip.gov.tr/content/annualReport/2011_Annual_Report_DASK.pdf > (accessed on 14 December 2015).

[12] C. Dipla, G. Kostakos, and Z. Nikolaos, The status of the Greek islets "Imia", 1996, < http://www.eliamep.gr/old/eliamep/files/96IMIA.pdf > (accessed 14 December 2015).

[13] S. Economides, S, 'The Europeanisation of Greek Foreign Policy', West European Politics, 28(2), 2005, pp. 471-491.

[14] EMAK, '2nd Committee Meeting of JHET-SDRU', 29 April 2010, < http://1emakdason.blogspot.com/2010_04_01_archive.html > (accessed 14 December 2015).

[15] J. Enia, Peace in its Wake? The 2004 Tsunami and Internal Conflict in Indonesia and Sri Lanka, Journal of Public and International Affairs, 19, 2008, pp. 7-27.

[16] S.N. Ertürk and F. Yonsel, An Application of the Adam Model for Pollution and Oil Spill Tracking in Bosphorous, 2002, < http://www.gidb.itu.edu.tr/staff/erturk/ISWA2002.pdf > (accessed on 14 December 2015).

[17] European Parliament, Written Question by Panagiotis Beglitis to the European Commission 12 December 2005 P-4764/05, http://www.europarl.europa.eu/sides/getDoc.do?type=WQ\&reference=P-20054764\&language $=\mathrm{EN}>($ accessed 14 December 2015).

[18] European Parliament, Answer given by Mr Hahn on behalf of the Commission, 17 June 2010, $<\quad$ http://www.europarl.europa.eu/sides/getAllAnswers.do?reference=E-20101022\&language=EN > (accessed 14 December 2015).

[19] JC Gaillard, E. Clavé and I. Kelman, 'Wave of peace? Tsunami disaster diplomacy in Aceh, Indonesia', Geoforum, 39(1), 2008, pp. 511-526. 
[20] E. Ganapati, I. Kelman, and T. Koukis 'Analyzing Greek-Turkish Disaster-related Cooperation: A Disaster Diplomacy Perspective', Cooperation and Conflict, 45(2), 2010, pp. 162-185.

[21] General Secretariat for Civil Protection, The UN and Civil Protection, Hellenic Ministry of Interior, General Secretariat for Civil Protection, 2010, < http://www.gscp.gr/ggpp/site/home/ws/units/primary+menu/organismoi/OHE/UN+OCHA.csp $>$ (accessed 14 December 2015).

[22] M. H. Glantz, The Politics of Natural Disaster: The Case of the Sahel Drought, Praeger, New York, NY, 1976.

[23] M.H. Glantz, 'Climate-Related Disaster Diplomacy: A US-Cuban Case Study', Cambridge Review of International Affairs, XIV(1), 2000, pp. 233-253.

[24] Hellenic Ministry of Citizen Protection, 'Press release for the completion of the Joint GreekTurkish exercise for the rescue of earthquake victims in the presence of the Minister of Citizen Protection Mr. Christos Papoutsis', 2010, < http://www.minocp.gov.gr/index.php?option=ozo_content\&perform=view\&id=3380\&Itemid= $459>$ (accessed 14 December 2015).

[25] Hellenic Ministry of Foreign Affairs, Statements of Foreign Minister Ms. Dora Bakoyannis and her Turkish Counterpart Mr Ali Babacan following their meeting, Athens, 4 December 2007, < http://www.mfa.gr/www.mfa.gr/Articles/en-US/041207_McC1101.htm > (accessed 15 December 2010).

[26] Hellenic Parliament, Parliamentary Minutes, 30 March 2007, p. 7785, < http://www.hellenicparliament.gr/UserFiles/a08fc2dd-61a9-4a83-b09a09f4c564609d/es30032007.pdf > (accessed 14 December 2015).

[27] A. Holloway, 'Drought Emergency, Yes ... Drought Disaster, No: Southern Africa 1991-93', Cambridge Review of International Affairs, XIV(1), 2000, pp. 254-276.

[28] Hürriyet, 'Perastikasu Gitonamu', Hürriyet, 8 September 1999.

[29] Hürriyet, 'Turkey and Greece need trade, not tanks, say EU negotiator', Hürriyet, 25 October 2010, < http://www.hurriyetdailynews.com/n.php?n=turkey--greece-need-not-tanks-but-trade-says-eu-negotiator-2010-10-25 > (accessed on 14 December 2015).

[30] Intergovernmental Oceanographic Commission, Intergovernmental Coordination Group for the Tsunami Early Warning and Mitigation System in the North-Eastern Atlantic, the Mediterranean and connected seas (ICG/NEAMTWS), Fifth Session, Athens, Greece 3-5 November 2008, UNESCO, Paris, 2008 < http://unesdoc.unesco.org/images/0018/001828/182884e.pdf > (accessed on 14 December 2015). 


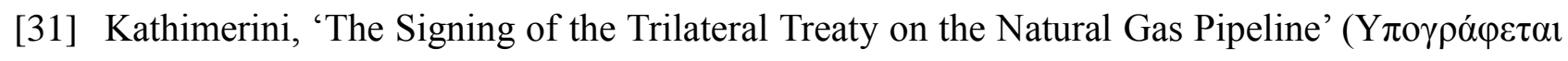

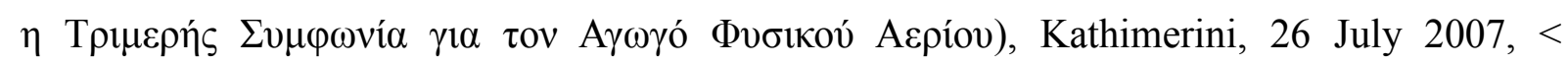
http://news.kathimerini.gr/4dcgi/_w_articles_economy_1_26/07/2007_235605 >, (accessed 14 December 2015).

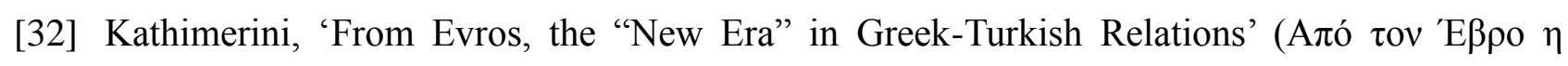

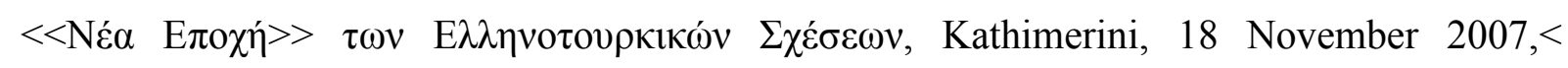
http://news.kathimerini.gr/4dcgi/_w_articles_politics_2_18/11/2007_249474 > (accessed 14 December 2015).

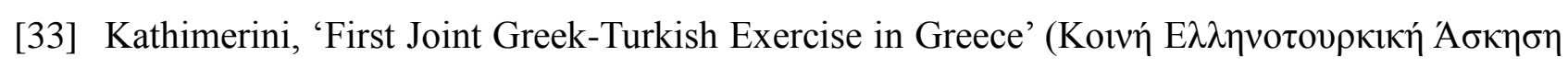

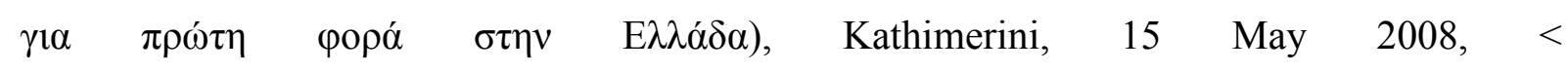
http://www.ekathimerini.gr/4dcgi/_w_articles_politics_1_15/05/2008_269968> (accessed 14 December 2015).

[34] Kathimerini, 'Greek-Turkish rift on tsunamis, Scientists stress the need for the immediate

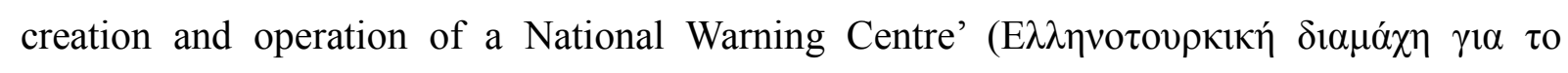

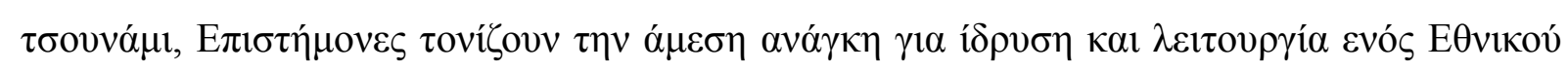

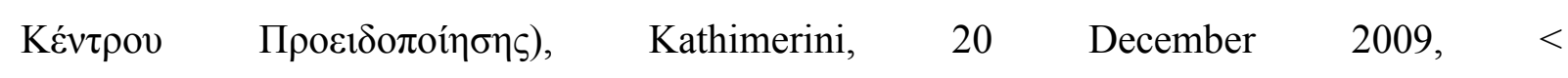
http://news.kathimerini.gr/4dcgi/_w_articles_ell_2_20/12/2009_384263 > (accessed 14 December 2015).

[35] Kathimerini, 'Low-politics, high expectations, Erdogan and Papandreou discussed everything,

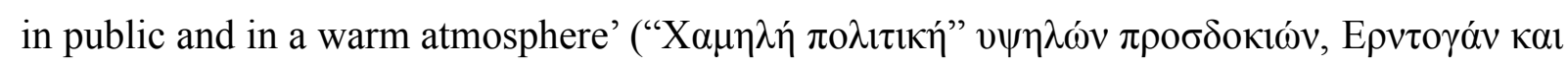

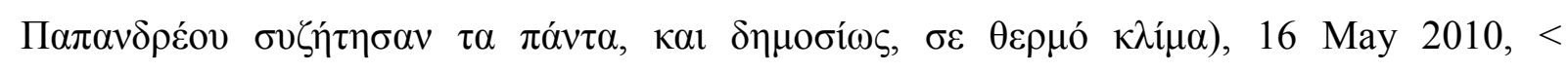
http://news.kathimerini.gr/4dcgi/_w_articles_politics_1_16/05/2010_401252 > (accessed 14 December 2015).

[36] I. Kelman, 'Hurricane Katrina Disaster Diplomacy’, Disasters, 31(3), 2007, pp. 288-309.

[37] I. Kelman, Disaster Diplomacy: How Disasters Affect Peace and Conflict, Routledge, Abingdon, U.K., 2012.

[38] I. Kelman and T. Koukis, 'Disaster Diplomacy', Cambridge Review of International Affairs, XIV(1), 2000, pp. 214-294.

[39] D. Keridis, 'Earthquakes, Diplomacy and New Thinking in Foreign Policy', The Fletcher Forum of World Affairs, 30(1), 2006, pp. 207-214.

[40] J. Ker-Lindsay, 'Greek-Turkish Rapprochement: The Impact of Disaster Diplomacy?', Cambridge Review of International Affairs, 14(1), 2000, pp. 215-232.

[41] J. Ker-Lindsay, Crisis and Conciliation: A Year of Rapprochement Between Greece and Turkey, Palgrave Macmillan, New York, NY, 2007. 
[42] A. Kibaroglu and V. Sumer, 'A Flashpoint in EU-Turkey Water Relations: The Meric Transboundary River Basin and Its Implications on the European Union's Flood Directive', Paper presented at the 2nd Global International Studies Conference, Ljubljana, Slovenia, 2326 July 2008.

[43] S. Kinzer, 'Earthquakes Help Warm Greek-Turkish Relations', New York Times, 13 September 1999, p. A1.

[44] M. Klimesova, Using Carrots to Bring Peace? Negotiation and Third Party Involvement, World Scientific, Singapore, 2016.

[45] N. Klitzsch, Disaster politics or disaster of politics? Post-tsunami conflict transformation in Sri Lanka and Aceh, Indonesia, Cooperation and Conflict, 49(4), 2014, pp. 554-573.

[46] V. Kotsis, 'Turkey is a friendly country for investments', ( Тоиркі́ $\alpha$, To Vima, 23 May 2010, < http://www.tovima.gr/finance/financebusiness/article/?aid=333424 > (accessed on 14 December 2015).

[47] E. Lannon and I. Martín, Report on Euro-Mediterranean partnership, status \& progress 2009, Documents IEMed, European Institute of the Mediterranean (IEMed), 2009, < http://www.iemed.org/publicacions/10_02_25_Report_BCN_Progress_Lannon_Martin.pdf > (accessed on 14 December 2015).

[48] P. Le Billon and A. Waizenegger, 'Peace in the Wake of Disaster? Secessionist Conflicts and the 2004 Indian Ocean Tsunami', Transactions of the Institute of British Geographers, 32(3), 2007, pp. 411-427.

[49] N.G. Loizides, 'Elite Framing and Conflict Transformation in Turkey', Parliamentary Affairs, 62(2), 2009, pp. 278-297.

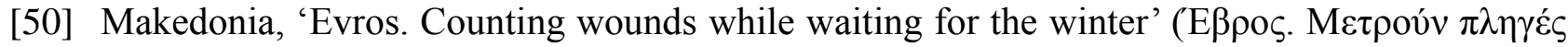

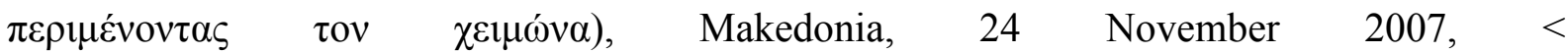
http://www.makthes.gr/index.php?name=News\&file=article\&sid=9388 > $\quad($ accessed 12 December 2010).

[51] K. Makropoulos, Natural Disasters, Earthquakes and Protective Measures, < http://library.tee.gr/digital/m2173/m2173_makropoulos.pdf > (accessed on 14 December 2015).

[52] S. Mavrogenis and I. Kelman, 'Perceptions of Greece-Turkey Disaster Diplomacy: Europeanization and the Underdog Culture', Balkanistica, 26, 2013, pp. 73-104.

[53] C. Migdalovitz, 'Greece Update', CRS Report for Congress, 16 December 2009, Congressional Research Service, Washington, D.C., < http://www.fas.org/sgp/crs/row/RS21855.pdf > (accessed 14 December 2015). 
[54] Y. Mylopoulos, E. Kolokytha, D. Vagiona, E. Kampragou, and E. Eleftheriadou, 'Hydrodiplomacy in practice: Transboundary water management in Northern Greece', Global Nest Journal, 10(3), 2007, pp. 287-294.

[55] T. Oguzlu, 'How Encouraging is the Latest Turkish-Greek Reconciliation Process?', Journal of Contemporary European Studies, 12(1), 2004, pp. 93-107.

[56] R. S. Olson and A.C. Drury. Un-therapeutic communities: a cross-national analysis of postdisaster political unrest. International Journal of Mass Emergencies and Disasters, 15(2), 1997, 221-238.

[57] U. Özkırıml1, and S.A. Sofos, Tormented by History: Nationalism in Greece and Turkey, Hurst \& Company, London, 2008.

[58] G.A. Papadopoulos, E. Daskalaki, A. Fokaefs, and N. Giraleas, 'Tsunami hazards in the Eastern Mediterranean: strong earthquakes and tsunamis in the East Hellenic Arc and Trench system', Natural Hazards and Earth Systems Science, 7, 2007, pp. 57-64.

[59] Prefecture of Xanthi, 'Second meeting of Prefects in the framework of cross-border

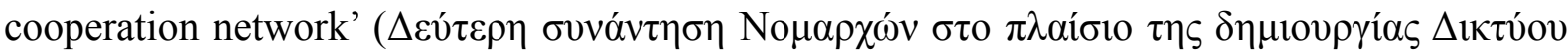

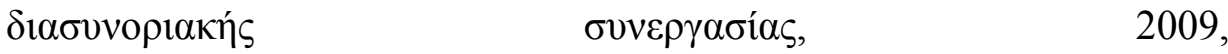
http://www.xanthi.gr/index.php?tmp=2\&id=200912\&path=1134 > (accessed 8 October 2010).

[60] Prevention Web, 'A new change in the disaster management structure of Turkey', 17 December 2009, < http://www.preventionweb.net/files/12840_anewchangeEN.pdf > (accessed 14 December 2015).

[61] E. L. Quarantelli and R. R. Dynes, Community conflict: its absence and presence in natural disasters' Mass Emergencies, 1, 1976, 139-152.

[62] Republic of Turkey, Pre-Accession Economic Programme 2006, Ankara, Turkey, November 2006, < http://ec.europa.eu/economy_finance/publications/publication11978_en.pdf > (accessed 14 December 2015).

[63] Republic of Turkey, Turkish Republic, Country Report on Disaster Management, Ankara, Turkey, 2008, < http://www.preventionweb.net/files/8359_8359TurkeyDRM2008.pdf > (accessed 14 December 2015).

[64] B. Rumelili, 'Transforming Conflicts on EU Borders: the Case of Greek-Turkish Relations', Journal of Common Market Studies, 45(1), 2007, pp. 105-126.

[65] S. Sagramola, D. Alexander, and I. Kelman, Major Hazards and People with Disabilities: A toolkit for good practice, Council of Europe, Strasbourg, France, 2015.

[66] S. Skias and A. Kallioras, 'Cross Border Co-operation and the problem of flooding in the Evros Delta' in M. Wiering and J. Verwijmeren (eds), Many Rivers to Cross: Cross Border Co-operation in River Management, Eburon, Delft, the Netherlands, 2007, pp. 119-143. 
[67] Stockholm International Peace Research Institute (SIPRI), The Confidence Building Measures between Greece and Turkey, SIPRI, Stockholm, Sweden, 2003,< http://www.sipri.org/contents/worldsec/nk/2000_2003_CBMs_Greece_Turkey.pdf (accessed 5 June 2008).

[68] P. A. Streich and D.B. Mislan, What follows the storm? Research on the effect of disasters on conflict and cooperation, Global Change, Peace \& Security, 26(1), 2013, pp. 55-70.

[69] To Vima, 'Papandreou Erdogan Press Conference, Cyprus and the Aegean at the spotlight - A

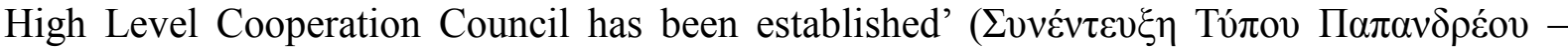

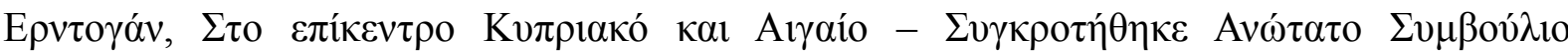
$\begin{array}{llll}\Sigma v v \varepsilon \rho \gamma \alpha \sigma i ́ \alpha \varsigma), & \text { May } & 2010,\end{array}$ http://www.tovima.gr/default.asp?pid=2\&ct=32\&artid=331726\&dt=14/05/2010 > (accessed 14 December 2015).

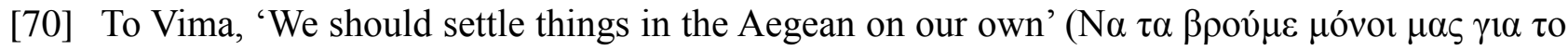
Airoío), $\quad 15 \quad$ May 2010, http://www.tovima.gr/default.asp?pid=2\&ct=32\&artid=331749\&dt=15/05/2010 > (accessed 14 December 2015).

[71] UNCTAD, Review of Maritime Transport 2015, UNCTAD/RMT (*), location, 2015, < http://unctad.org/en/PublicationsLibrary/rmt2015_en.pdf > (accessed 4 March 2016).

[72] UNISDR, Hyogo framework for action 2005-2015: Building the resilience of nations and communities to disasters, UNISDR (United Nations International Strategy for Disaster Reduction), Geneva, Switzerland, 2005.

[73] UNISDR, Disaster risk reduction in Europe: Overview of European national platforms, Hyogo Framework for Action focal points and regional organizations/institutions, Updated version of Report on Implementation of the Hyogo Framework for Action: Europe ISDR/GP/2007/Inf. 6, UNISDR (United Nations International Strategy for Disaster Reduction), Geneva, Switzerland, 20 May 2008.

[74] UNISDR, Sendai framework for disaster risk reduction 2015-2030, UNISDR (United Nations Office for Disaster Risk Reduction), Geneva, Switzerland, 2015.

[75] M. Warnaar, 'Shaken, Not Stirred: Iran's Foreign Relations and the 2003 Bam Earthquake', in S.R. Sensarma and A. Sarkar (eds), Disaster Risk Management: Conflict and Cooperation, Concept Publishing, New Delhi, India, 2013, pp. 238-267.

[76] World Bank and UNISDR, South Eastern Europe, Disaster Risk Mitigation and Adaptation Programme, Sustainable Development Department Europe and Central Asia Region and UNISDR secretariat Europe, The World Bank and UNISDR, Washington, D.C. and Geneva, Switzerland, 2008. 
[77] A. Yalçinkaya, 'From Disaster Solidarity to Interest Solidarity: Turkish-Greek Relations after the Marmara and Athens Earthquakes within the Concept of Game Theory', Turkish Review of Balkan Studies, 2003, pp. 149-202.

[78] E. S. Yim, D. W. Callaway, S. Fares, and G. R. Ciottone, 'Disaster Diplomacy: Current Controversies and Future Prospects', Prehospital and Disaster Medicine, 24(4), 2009, pp. 291293. 